\title{
Aturan Percakapan Aa Gym dalam Dakwah
}

\author{
Wahyu Dinata ${ }^{1}$, Restu Triarti Putri ${ }^{2}$ \\ 1Universitas Islam Sunan Gunung Djati, Bandung, Indonesia, \\ dinatawahyu17@gmail.com. \\ 2 Universitas Islam Sunan Gunung Djati, Bandung, Indonesia, \\ triartiputri@gmail.com.
}

\begin{abstract}
ABSTRAK
Sekian banyak ustadz yang berdakwah, Aa Gym salah satu ustadz yang menarik untuk diteliti, lantaran perkataannya banyak membuat orang tafakur dan sadar diri, sehingga banyak para jamaah yang hadir secara rutin ke pengajiannya. Tujuan dari penelitian ini adalah untuk mengetahui aturan percakapan Aa Gym dalam dakwah nya, yang meliputi : bagaimana perkataan kuantitasnya, perkataan berkualitasnya, perkataan relevannya, dan perkataan berprilakunya. Sehingga menarik untuk dibahas. Adapun metode yang digunakan adalah Metode penelitian menggunakan metode kualitatif deskriptif, dimaksudkan agar mempermudah mendeskripsikan suatu kasus yang lebih spesifik. Hasil penelitian ini ditemukan bahwa dakwah Aa Gym memenuhi standart teori aturan percakapan yang ditemukan oleh Paul Grice yang mana percakapan Aa Gym dengan jamaah nya menggunakan perkataan berkuantitas (quantity maxim), perkataan berkualitas (quality maxim), perkataan relevan (relevancy maxim) maupun perkataan berprilaku (manner maxim). Adapun penelitian ini memperkaya kajian komunikasi islam dalam kajian khitobah atau tabligh dalam memanfaatkan teori komunikasi dari Paul Grice.
\end{abstract}

Kata kunci : Aturan percakapan, Aa Gym, Dakwah.

\section{ABSTRACT}

There are so many ustadz who preach, Aa Gym is one of the ustadz who is 
W Dinata, RT Putri.

interesting to research, because his words make people think and self-conscious, so many congregations attend regularly to his recitation. The purpose of this study was to determine the conversation rules of Aa Gym in his preaching, which include: how are the words of quantity, words of quality, relevant words, and words of behavior. So it is interesting to discuss. The method used is a descriptive qualitative research method, making it easier to describe a more specific case. The results of the study found that Aa Gym's da'wah met the appropriate theoretical standards found by Paul Grice which related Aa Gym to its congregation using words of quantity (maxim of quantity), words of quality (maxim of quality), words of relevance (maxim of relevance) and words of behavior (the saying goes). This research enriches the study of Islamic communication in the study of khitobah or tabligh in utilizing Paul Grice's theory of communication

Keywords : rules of conversation, aa gym, preaches

\section{PENDAHULUAN}

Islam menyebar di seluruh dunia tidak bisa dipungkiri lantaran disana ada proses dakwahnya, salah satu bentuk dakwah ialah bertabligh atau ceramah, di depan khlayak ramai. Dengan tujuan menghantarkan orang untuk kenal dan cinta kepada Tuhan nya ialah Allah Swt.

Meningkatnya pemahaman agama maka meningkat pula keimanan, kesadaran dan perbuatan. Dimana syariat Islam menjadi tolak ukur dakwah Islam, Al-Qur'an dan Hadits adalah sebagai pijakan utama dalam dakwah. Dalam prosesnya dakwah melibatka beberapa unsur seperti da'i (orang yang berdakwah), pesan dakwah, metode dakwah, media dakwah, dan mad'u (sasaran dakwah). Dakwah sebagai proses penyampaian ajaran Islam mengajarkan tiga hal seperti yang dijelaskan dalam Hadits (Al-Bukhari : VII : 149), yaitu kesetaraan gender dalam dakwah, kewajiban berdakwah dan pesan dakwah sesuai dengan keadaan penerima dakwah. (Dadang Muliawan, Irham Ramdani,2020)

Sejatinya Dakwah Islam yang dilaksanakan berupaya untuk menegakkan kepribadian yang berakhlaqul karimah. Herman Soewardi (2003: 26) mengajukan 3 (tiga) tujuan operasional dakwah, yaitu: menjadikan orang 
lurus dan benar dengan melakukan kebaikan dan menghilangkan kemungkaran (amar ma'ruf dan nahyi munkar); melahirkan kekuatan pada diri seseorang melalui karya-karyanya; karsa; tinggi profesionalisme di bidang masing-masing. Dakwah Islam diarahkan pada terbinanya kesalehan pribadi dan sosial. Artinya, seorang pendakwah dirasa perlu memahami tujuan dakwah itu sendiri sehingga bagaimana caranya pendakwah melalukan komunikasi dakwah yang efektif untuk mewujudkan tujuan dakwah islam itu sendiri.

Adapun sejarah mencatat bahwa para kiai yang berdakwah telah memberikan sumbangan kepada bangsa Indonesia sejak dulu. Sebagai pribadi, ia melaksanakan dakwah di masyarakat. Selain berdakwah bagi diri sendiri, seorang kiyai yang biasanya mendirikan pondok pesantren untuk mengembangkan dan mengaplikasikan dakwahnya kepada masyarakat. Sebagai pimpinan pesantren, ia membimbing masyarakat untuk mandiri dan memeroleh kemajuan dalam berbagai bidang, sehingga mereka dapat memperoleh penerangan batin. "Pesantren berperan dalam kegiatan politik, kegiatan perdagangan, dan pembukaan daerah pemukiman baru" (Rahardjo, 1995: 10)

Dalam proses dakwah tentunya seorang dai harus menguasai beberapa ilmu, sudah tentu ilmu keislaman, selain itu perlu juga bagi seorang Dai untuk menguasai ilmu-ilmu pendukung lainnya seperti ilmu komunikasi. Yang menurut penulis ilmu ini sangat penting untuk diketahui bagi siapa pun, terutama seorang dai, yang mana merekalah yang akan menjadi penyalur pesan-pesan islam, sehingga membuat islam makin jaya dan berkembang. Salah dalam berkomunikasi maka akan salah dalam pemaknaan, salah pemaknaan maka akan menghantarkan pada prespsi yang negative.

Tentunya dalam setiap ilmu ada aturannya, tidak terkecuali ilmu komunikasi, yang mana ilmu komunikasi memiliki aturan, sebagaimana kita ketahui diantara banyak nya teori salah satunya adalah teori aturan dalam percakapan, sehingga menghantarkan seorang dai mempunyai 
W Dinata, RT Putri.

panduan ketika berinteraksi dalam dakwahnya. Agar dakwahnya diterima, dicintai, dan dinanti nanti kehadirannya.

Dalam berdakwah, para aktifis dakwah harus pandai memilih bahasa sedemikian rupa sehingga ummat tidak tersinggung tetapi justru dapat tersentuh hatinya (Thaha, 1997: 148). Di samping gaya retorika, hal lain yang menentukan efektifitas dakwah yaitu penguasaan massa, penguasaan persoalan yang dibahas, dan yang terpenting adalah keikhlasan pembicara. Apa yang dari hati akan sampai ke hati, sedangkan apa yang hanya keluar dari bibir biasanya hanya akan sampai ke telinga (Thaha, 1997:119). Sehingga pendakwah harus memahami cara bagaimana agar dakwah yang disampaikan dapat menyentuh aspek psikologis ummat agar setiap pesan yang disamaikan oleh pendakwahersebut dapat membuat umat tertegun dan mau menerima pesan keagamaan yang disampaikannya.

Dari sekian banyak ustadz atau pendakwah yang ada di Indonesia, lebih tepatnya di bandung (karena penulis bermukim di bandung), penulis lebih tertarik untuk meneliti Aa Gym sebagai objeck penelitiannya, karena menurut hemat penulis, beliau merupakan salah satu ulama yang banyak pengikutnya atau banyak jamaah nya, dan komunikasi dengan jamaahnya pun enak untuk didengar, menyejukan, dan menimbukan rasa kangen kembali untuk mengikuti kajian nya lagi.

Sebagai pendakwah terkenal sebagai publik figur yag memiliki banyak penggemar, Aa Gym memiliki komitmen yang sangat kuat pada penyebaran ajaran "Islam sebagai rahmatan lil'alamin" dengan tetap berpegang teguh pada prinsip tauhid dan akhlaqul karimah, kebersihan hati, keikhlasan, dan kebersamaan, termasuk dalam menyikapi setiap perbedaan. Aa Gym menyatakan, "Perbedaan adalah kenyataan. Bagaimana menyikapi perbedaan menuju ridha Allah ... itulah tantangannya" (Gymnastiar, 2005:63). "Saya ingin mengaplikasikan Islam sebagai rahmatan lil'alamin" (Gymnastiar, 2005:77). "Saya bercita-cita Daarut Tauhid sebagai miniatur Indonesia dengan menunjukkan wajah 
Islam yang indah, produktif, profesional, dan membawa rahmat bagi seisi alam" (Gymnastiar, 2005:97).

Jika ditinjau dari hasil penelitian sebelumnya penelitian yang saling terkait membahas tentang aturan percakapan belum penulis temukan, baik itu di skripsi, jurnal, maupun lainnya. Tapi kalau untuk penelitian Aa Gym sebagai objeck nya, penulis pernah menemuinya, yaitu dengan judul skripsi "Retorika Dakwah KH. Abdullah Gymnastiar (Aa Gym) Pimpinan Pondok Pesantren Daarut Tauhiid Gegerkalong Bandung" di tahun 2002 yang ditulis oleh Miftah, yang menjelaskan tentang dimensi retorika. Hasil penelitian ini menghasilkan bahwa melalui kaset CD ceramahnya sudah memenuhi dimensi retorika yang sebagian besar ceramah beliau sudah menggunakan kaidah retorika yang benar. (Miftah, 2002: 13)

Adapun kesamaannya adalah object yang di teliti, sama-sama Aa Gym yang jadi perbedaannya adalah titik fokusnya. Yaitu focus pada penelitian ini untuk mengetahui bagaimana aturan percakapan Aa Gym dalam dakwahnya, melalui teori aturan percakapan paul grice yang mana meliputi mulai dari: perkataan berkualitas, perkataan berkuantitas, perkataan relevan hingga perkataan berprilaku.

Dari latar belakang masalah diatas dapat kita rumuskan beberapa masalah yaitu: Bagaimana aturan percakapan Aa Gym dalam dakwahnya yang meliputi: perkataan berkualitas, perkataan berkuantitas, perkataan relevan hingga perkataan berprilaku.

Adapun harapan penulis terhadap penelitian ini adalah untuk mengetahui apakah komunikasi atau dakwah Aa gym sesuai dengan kaidah-kaidah teori ilmiah yaitu teori aturan percakapan dari Paul Grice, kedua mudah-mudahan hasil penelitian ini jadi jalan kebermanfaatan bagi yang membutuhkan nya, baik dari kalangan akademik maupun kalangan umum lainnya. 
W Dinata, RT Putri.

Metode yang digunakan dalam penelitian ini adalah menggunakan metode atau pendekatan penelitian studi kasus kualitatif dimaksudkan agar mempermudah mendeskripsikan suatu kasus yang lebih spesifik (baik kejadian maupun fenomena tertentu) mengenai aturan percakapan Aa Gym dalam ceramahnya. Teknik pengumpulan data yang digunakan dalam penelitian ini melalui observasi, wawancara dan dokumentasi.

\section{LANDASAN TEORITIS}

Menurut A.W. Wijaya (2000: 15) komunikasi adalah penyampaian informasi dan pengertian dari seseorang kepada orang lain. Komunikasi akan dapat berhasil apabila sekiranya timbul saling pengertian, yaitu jika kedua belah pihak, baik antara pihak pengirim (komunikator) dan pihak penerima (komunikan) informasi dapat memahaminya. Hal ini tidak berarti bahwa kedua belah pihak harus menyetujui sesuatu gagasan tersebut, tetapi yang penting adalah kedua belah pihak sama-sama memahami gagasan tersebut. Dalam keadaan seperti inilah baru dapat dikatakan komunikasi telah berhasil baik (komunikatif).

Berdasarkan hal tersebut berarti komunikasi yang efektif adalah komunikasi yang mampu diterima dan dipahami oleh kedua belah pihak antara komunikator dengan komunikan agar tujuan dari komunikasi dan pesan informasi diterima dan dipahami dengan baik. Komunikasi dan dakwah adalah dua hal yang tidak dapat dipisahkan atau satu sama lain saling terkait, dimana Da'I (pendakwah) sebagai komunikator dan Mad'u (jamaah) sebagai komunikan, artinya agar dakwah berlangsung dengan baik maka harus ada komunikasi yang efektif didalamnya.

Persoalan komunikasi yang menjadi perhatian dalam hubungan antar manusia terutama dalam kaitannya dengan aktivitas dakwah adalah bagaimana komunikasi yang dilakukan dapat berlangsung secara efektif (berguna) terhadap mad'u (Sayyid Muhammad Nuh, 2004: 121). Komunikasi dakwah menjadi efektif jika materi dakwah disampaikan oleh penceramah atau dā'i, sedemikian rupa sehingga dapat dimengerti sepenuhnya oleh audience atau mustami'. (A. Markarma,2014) 
Komunikasi yang efektif bukan hanya sekedar menyusun kata atau mengeluarkan bunyi yang berupa kata-kata, tetapi menyankut bagaimana agar orang lain tertarik perhatiannya, mau mendengar, mengerti dan melakukan sesuai dengan pesan yang disampaikan (Sayyid Muhammad Nuh, 2004: 145). Dalam penyampaiannya, komunikasi yang berlangsung melalui percakapan memiliki beberapa aturan agar terjalin komunikasi yang efektif, dalam aktifitas dakwah, berarti perlu dipahami adanya aturan percakapan yang baik antara seorang pendakwah terhadap jamaah agar terjalin komunikasi yang efektif sehingga pesan dakwah dapat diterima, dihayati, dipahami secara positif dan tujuan dakwah pun berhasil terwujud melalui komunikasi yang berlangsung antara pendakwah dengan jamaah.

Teori yang dijadikan landasan dalam penelitian ini ialah teori komunikasi, yang berkaitan erat dengan percakapan, yang mana percakapan merupakan manifestasi penggunaan bahasa untuk berinteraksi. (Pragmatics, 2001: 137) Adapun teori yang dipakai \& difokuskan adalah teori aturan percakapan dari Paul Grice yang mana beliau menjelaskan bahwa percakapan itu idealnya harus koheran yang berarti harus logis dan mudah dimengerti. Kerjasama tidak bisa dipungkiri merupakan kunci utama dalam terjalin nya komunikasi yang efektif.

Misalnya jika seseorang mengajukan pertanyaan kepada anda, maka anda harus menjawab atau menanggapinya dengan cara yang sekurangkurangnya anda mengakui adanya pertanyaan. Jika tidak, maka anda akan dinilai kurang sopan. Begitu juga sebaliknya kita, kitapun akan merasa kurang nyaman apabila ada orang yang berbicara dengan kita tapi tidak menyelesaikan kata-katanya sehingga menimbulkan kebingungan, yang berakibat pada percakapan menjadi tidak koheran.

Percakapan merupakan suatu bentuk aktivitas kerjasama yang berupa interaksi komunikatif sebagaimana dinyatakan oleh Gumperz dalam Rustono (1999: 48). Percakapan adalah interaksi verbal yang berlangsung secara tertib dan teratur yang melibatkan dua pihak atau lebih guna 
W Dinata, RT Putri.

mencapai tujuan tertentu (Rustono, 1999: 50).

Dalam melakukan percakapan atau pertuturan, kadangkala maksud atau makna yang dituturkan mempunyai arti langsung dan tidak langsung. Seorang penutur dalam melakukan pertuturan sebaiknya memenuhi kaidah-kaidah dalam percakapan, agar maksudnya mudah dipahami oleh mitra tutur atau pendengar. Namun demikian, sengaja atau tidak sengaja kadang mereka melanggar kaidah-kaidah tersebut. Hal ini mengakibatkan timbulnya sesuatu yang terimplikasi atau sesuatu yang implisit dalam penggunaan bahasa (Mey 1993: 99). Disamping itu, dalam percakapan mungkin terjadi implikasi berupa proposisi yang bukan bagian dari tuturan tersebut. Dengan kata lain, dalam percakapan implikasi tuturan dapat dipahami dari apa yang mungkin diartikan, disiratkan atau dimaksudkan (Rustono 1999: 43).

Grice (melalui Wijana, 1996: 46) mengemukakan bahwa dalam rangka melaksanakan prinsip kerja sama itu, setiap penutur harus mematuhi empat maksim percakapan (conversational maxim), yaitu maksim kuantitas (maxim of quantity), maksim kualitas (maxim of quality), maksim relevansi (maxim of relevance) dan maksim pelaksanaan (maxim of manner)

Adapun menurut Grise, kerjasama dengan percakapan dapat dicapai melalui empat aturan yaitu :

1. Perkataan berkuantitas (quantity maxim)

Maksim ini mengharapkan agar peserta tutur memberikan respons atau jawaban secukupnya atau sebanyak yang dibutuhkan lawan tutur saja. Contohnya ketika seseorang ditanya siapa namanya, maka dia tidak perlu memberikan jawaban selain informasi tentang namanya, seperti alamat, status, dan lain sebagainya.

2. Perkataan berkualitas (quality maxim)

Maksim percakapan ini mengharuskan setiap partisipan komunikasi mengatakan hal yang sebenarnya. Artinya jawaban atau respons hendaknya didasarkan pada bukti yang memadai. Contohnya ketika seorang murid ditanya gurunya apa ibukota Jepang, maka dia kalau memang tahu harus menjawab Tokyo, 
karena hal tersebut tidak terbantahkan lagi. Namun, bisa saja terjadi kesengajaan, seorang penutur melanggar maksim kualitas ini. Hal ini tentu mempunyai maksud seperti menimbulkan efek lucu (Wijana, 1996:49)

3. Perkataan relevan (relevancy maxim)

Maksim relevansi mewajibkan setiap peserta tutur memberikan kontribusi relevan dengan pokok pembicaraan. Maksim relevansi menekankan keterkaitan isi tuturan antar peserta percakapan. Setiap peserta percakapan saling memberikan kontribusi yang relevan dengan topik pembicaraan sehingga tujuan percakapan dapat tercapai secara efektif. Namun, terkadang secara tersurat (eksplisit) respons yang diberikan tidak terlihat relevansinya dengan pokok pembicaraan, karena sudah ada latar belakang pengetahuan (background knowledge) yang sama antara penutur dan lawan tutur maka komunikasi masih tetap bisa berjalan. Dengan kata lain, yang tersurat (eksplisit) nampak tidak relevan namun, yang tersirat (implisit) sebenarnya relevan

4. Perkataan berprilaku (manner maxim) (Morissan, 2013: 238)

Maksim pelaksanaan mengharuskan setiap peserta percakapan berbicara secara langsung, tidak kabur, tidak taksa, secara runtut dan tidak berlebih-lebihan. Bila hal ini dilanggar, biasanya penutur mempunyai tujuan tertentu, misalnya mengelabuhi, menimbulkan efek lucu, dan tujuan tertentu lainnya.

\section{HASIL DAN PEMBAHASAN}

KH.Abdullah Gymnastiar atau yang lebih dikenal dengan nama Aa Gym merupakan salah satu ulama yang terkenal sebagai pendakwah yang memiliki banyak jamaah, penulis buku, pebisnis yang memiliki banyak usaha, salah satunya sekaligus pendiri pondok pesantren Daarut Tauhiid yang ada di Bandung yang terkenal dengan ceramahnya yang diklaim menyejukkan hati dan banyaknya jamaah yang tergabung dalam pengajian dan pondok pesantren binaannya. 
Sepanjang karir Aa Gym berhasil menorehkan beberapa pencapaian prestasi yang cemerlang, dimana beliau sukses sebagai pendiri Manajemen Qolbu Coorperation yang merupakan sebuah holding company yang menaungi banyak usaha yang bergerak di berbagai bidang, dan beberapa usaha di bidang ekonomi lainnya yang didirikan oleh beliau untuk menopang aktifitas dakwah yang dilakukannya, selain menjadi pembina Yayasan Daarut Tauhiid dan pendiri pondok pesantren yang dikembangkannya, dalam kurun waktu tertentu beliau aktif menjadi pendakwah yang kerap tampil di berbagai program acara televisi nasional, dalam ceramahnya yang menyejukkan hati mampu menarik perhatian publik untuk menikmati pesan dakwah yang disampaikannya dan banyak yang menjadi jamaahnya yang mengikuti pengajian rutin yang diadakan di masjid Daarut Tauhiid.

Sebagai pendakwah, Aa Gym memiliki kemampuan berbicara dengan kapasitas dan kemampuan yang mumpuni, sehingga mampu menarik perhatian publik untuk mau mendengarkan isi ceramahnya yang dianggap mampu menyejukkan kalbu para pendengar, adapun isi pesan dakwahnya yang bercorak ma'rifatullah, keluarga sakinah, beberapa pesan dengan isi ceramah yang menyampaikan ajaran Islam secara santun, menyuarakan perdamaian dan menjaga kebersamaan, tidak memprovokasi dengan gaya penyampaian yang unik serta mampu mempengaruhi jamaah dengan siraman rohani yang berisi ajaran Islam yang dapat memberi jawaban atau solusi terhadap masalah kehidupan dan doa-doanya yang kerap membuat jamaah berderai air mata menjadikan setiap ceramahnya di berbagai pengajian ramai dikunjungi oleh jamaah.

Dalam aktifitas berdakwah, seorang da'I perlu memiliki kemampuan berkomunikasi (komunikasi efektif) yang agar penyampaian pesan dakwah agar mudah dipahami oleh mad'u. Dalam hal ini, Aa Gym dipandang memiliki kemampuan dan kapasias yang mumpuni dalam berdakwah, terbukti dengan respon jamaah yang menikmati isi ceramah Aa Gym yang dianggap menyejukan hati dengan tutur kata dan isi materi ceramah yang disampaikannya. 
Berkaitan dengan hal tersebut, sesuai dengan teori aturan percakapan agar mampu menjadikan komunikasi yang efektif, maka dapat disimpulkan beberapa hal mengenai kemampuan retorika dalam percakapan yang dilakukan seorang Aa Gym sebagai pendakwah yang mampu menyita perhatian banyak jamaah yang ditinjau dari berbagai hal, diantaranya sebagai berikut:

\section{(1) Perkataan berkuantitas Aa Gym dalam dakwahnya}

Secara sederhana, maksud dari perkataan kuantitas disini adalah perkataan yang efektive dan efisien, singkat, padat, dan jelas. Tidak kepanjangan, tidak juga kependekan, yang jelas pas, tepat dan profosional.

Misalnya dalam percakapan dakwah nya dengan jamaah, Aa Gym tidak neko-neko. Jelas, langsung ke point utama pembahasan. Sepertihalnya ketika beliau ceramah di Masjid Daarut Tauhiid Bandung, dalam satu sesi ada interatif tanya jawab dengan jamaah.

\section{Contoh Percakapan :}

Jamaah Pertama : "Assalammualaikum. Wr.wb. A, saya dedi, gimana sih caranya menghilangi rasa khawatir \& takut dengan sesuatu negative yang belum tentu terjadi?"

Aa Gym : "Gini, kita wajar mempunyai kecemasan kedepan kan "wallanabluwannaqum bisyain, Allah akan menghujamkan ke dalam diri kita sedikit ketakutan, macem-macem yaa. Ada masalah fisik, uang, penyakit, jodoh dsbnya. Nah makin lama mikirin yang ditakutin makin gelisah, solusinya bungkus kembalikan ke Allah, insha allah hati akan dibikin tenang."

Jamaah kedua : Assalammualaikum. Wr.wb. A, kita akhir-akhir ini mengalami banyak bencana alam, baik musibah banjir, tanah longsor, gempa bumi, dan lain-lain, yang jadi masalahnya, dari musibah ini ada Sebagian orang yang sibuk menyalahkan seseorang, oknum dsbnya, sehingga orang itu merasa terpojok, direndahkan, kami mohon tanggapan $\mathrm{Aa}^{\prime}$ : 
W Dinata, RT Putri.

Aa Gym : sebenernya ini karunia, untuk seseorang itu Latihan ikhlas, kalau sudah berbuat, lupakan, dan ini juga karunia penggur dosa kalau ada yang merendahkannya, mengghibahnya dsbnya. Ambil positife nya saja. Dan ini juga evaluasi untuk kita juga.

Jamaah Ketiga: Bagaimana menasehatkan suami yang sensitive kalau mau di ingetin?

Aa Gym : Sebenernya, orang jadi sensitife itu karena ilmunya terbatas, dan gimana cara menasehatinnya yaa dengan contoh bu. Berikan aja dengan contoh yang terbaik. Bisa melalui cerita, pakek pihak ketiga, sehingga suami tidak merasa di gurui.

Jamaah Keempat : Kalau ada non muslim yang mengucapkan salam ketika dia dating kerumah kita, kita ngejawabnya apay a $\mathrm{A}^{\prime}$ ?

Aa Gym : Jawabanya Waalaikum..Ini ilmu yang saya ketahui

Jamaah Kelima : A' kalau posting foto ketika pengajian boleh ngga yaa?

Aa Gym : Tergantung niatnya dek. Semua aktivitas kita pasti dilihat, pasti diketahui, dan pasti ada perhitungannya. Yang penting cukup Allah yang jadi tujuannya. (diambil dari dokumentasi dari channel youtube Aa Gym Official 12 desember 2018)

Berdasarkan kutipan percakapan dalam ceramah Aa Gym diatas, dapat disimpulkan bahwa Aa Gym dalam percakapannya dengan jamaah sudah menggunakan perkataan yang berkuantitas, sehingga jawaban nya proposional tidak kepanjangan tidak juga 
kependekan, melainkan cukup, sehingga komunikasinya bisa effective.

Dalam hal ini, kutipan percakapan di atas memenuhi kriteria percakapan berkuantitas, yaitu (1) informasi yang diberikan oleh penutur harus informatif dan (2) tidak boleh melebihi informasi yang dibutuhkan oleh lawan tutur (penutur). Dimana seorang penutur diharapkan dapat memberikan informasi yang cukup, relatif memadai, dan seinformatif mungkin. Informasi demikian tidak boleh melebihi informasi yang dibutuhkan oleh mitra tutur, dapat dikatakan melanggar maksim kuantitas dalam Prinsip Kerja Sama Grice. Hal tersebut sesuai dengan percakapan AaGym sehingga terjalin komunikasi yang efektif.

\section{(2) Perkataan berkualitas Aa Gym dalam dakwah nya}

Intisari perkataan berkualitas disini adalah bahwasannya perkataan yang benar, jujur, dan apadanya. Dan cukuplah anda disebut pembohong atau melanggar kaidah teori ini yaitu perkataan berkualitas, apabila anda berbicara dengan menunjukan suatu maksud yang tidak jujur.

Scott Jacobs dan temannya mengatakan bahwa kebohongan merupakan pelanggaran terhadap kaidah perkataan berkualitas yang bisa dilakukan dalam keadaan terbuka ataupun tertutup. Dan kebohongan yang tertutup dapat dilakukan jika melibatkan implikatur yang salah (Brashers, $1996: 63$ )

Contohnya : Seorang ayah yang ditanya anak nya, ayah puasa hari ini, tapi kemudian sang ayah menjawab puasa, padahal tadi baru selesai makan siang. Ini merupakan suatu kebohongan sehingga melanggar kaidah perkataan berkualitas (quality maxim)

Adapun dalam ceramah Aa Gym yang penulis simak, bahwasahnya Aa Gym lulus dan berhasil menggunakan perkataan berkualitas, lantaran penulis tidak menemukan perkataan- 
W Dinata, RT Putri.

perkataan yang berbohong dari isi ceramah maupun percakapan Aa Gym dengan jamaahnya. Sebagai sample penelitiannya, yang penulis kutip dari ceramah beliau di Masjid

Contoh Percakapan :

Jamaah: "Assalammualaikum Wr.Wb A, saya mau bertanya, Kenapa sih kita harus shalat? Setiap orang jawaaban nya beda-beda ketika saya tanya A, kira-kira menurut versi Aa bagaimana?"

Aa gym: "Jadi kayak orang buta, disuruh menjelaskan gajah, ada yang megang ekor, ada yang megang kaki, ada yang megang yaa semuanya cerita gajah. Saya juga mungkin beda lagi. Kalau saya yang tadi tuh, Bagi saya shalat itu moment yang sangat penting, karena saya mahluk yang berlumur dosa, saya ingin diampuni Allah, karena dalam solat ada tuh shalat itu mendatangkan ampunan, saya ini orang yang susah untuk patuh ke Allah, saya membutuhkan rahmat Allah supaya saya bisa di tolong jadi orang baik. Dan dalam solat ada warhamni, saya juga banyak sekali keperluan dan saya bingung bagaimana mencukupinya, dan solat itu membuka pintu kecukupan dari yang punya segala-galanya waj'burni dan saya juga ngga mau hidup saya hina di dunia maupun di akhirat. Saya ingin oleh Alloh diangkat derajat nya di sisi Allah. Ternyata ada dalam solat warhamni.

Saya juga sangat perlu dalam rezeki, beragam jenis rezeki dan itu yang punya Cuma Allah. Dan Allah janji dikasih kalau benar solatnya, wardzukni, saya bingung nih mau ngomong apa yang bener, niat saya supaya bener, saya ngurus amanah pesantren ini gimana supaya bener, dan saya juga ingin supaya sisa umur ini bener, saya perlu yang nuntun. Wahdini ada dalam shalat. Nah saya juga ngga mau penyakitan lahir batin, saya ingin sehat wal affiat, itu juga ada dalam solat, wa'afini. Saya ngga mau dosa-dosa saya yang banyak ini dibuka, saya pengen hapus semuanya, didunia hapus diakherat hapus, wa'fuanni, kita memerlukan shalat bener? Siapa yang tidak memerlukan itu tadi? Hanya orang sombong. Bener? Sudah hadirin, mudah-mudahan ada manfaatnya." (Dikutip : di 
Masjid Daaruut Tauhid, Kamis, 17 Juli 2017 Kajian kitab Al Hikam)

Berdasarkan kutipan percakapan dalam ceramah diatas dapat disimpulkan bahwa Aa Gym dalam ceramah dan percakapannya tampak menampilkan kejujuran, apadanya, sepertihalnya ketika beliau berkata "saya mahluk yang berlumur dosa, saya ingin diampuni Allah, saya butuh rahmat Allah, saya ingin sehat dsb nya" ini merupakan salah satu indikator bahwa beliau mengungkap kan sesuatu yang mana semua itu benar adanya, dan itu diperlukan seorang hamba, untuk meminta kepada Tuhannya. Dalam hal ini, kutipan percakapan di atas memenuhi kriteria percakapan berkualitas yaitu (1) jangan mengatakan sesuatu yang anda yakini bahwa itu tidak benar dan (2) jangan mengatakan sesuatu yang bukti kebenarannya kurang meyakinkan. Dimana seorang peserta tutur diharapkan dapat menyampaikan sesuatu yang nyata dan sesuai fakta sebenarnya di dalam bertutur. Fakta harus didukung dan didasarkan pada buktibukti yang jelas.

\section{(3) Perkataan Relevan Aa Gym dalam dakwah nya}

Sederhananya kata inti dari perkataan relevan (relevancy maxim) adalah perkataan yang nyambung, ada kaitan antara satu pembahasan dengan pembahasan yang lainnya. Sehingga ada kesinkronan dalam berkomunikasi yang mana menciptakan komunikasi yang efektif saling mengerti dan dimengerti.

Adapun contoh perkataan atau percakapan yang layak di sebut tidak relevan adalah sebagai berikut: misalnya Seorang ibu menyuruh sang anak untuk solat dengan melalui sebuah ungkapan pertanyaan "nak sudah solat belum? sudah masuk waktu dzuhur tuh" kemudian sang anak pun menjawab "Ibu masak apa hari ini?" tentunya sudah dapat dipastikan jawaban sang anak tidak relevan atau nyambung dengan pertanyaan yang diajukan sang ibu. Nah inilah disebut dengan melanggar kaida perkataan relevan (relevancy mixim) 
W Dinata, RT Putri.

Berikut kutipan ceramah Aa Gym ketika mengisi di Masjid Al Latief Blok M pasaraya Jakarta:

Percakapan:

Jamaah: "Saya nila Rosyam, dari serpong."

Aa Gym: "Gimana bu?"

Jamaah : "Assalammualaikum Wr.Wb Gini A', saat di masjid denger ceramah Aa saya pengen jadi Muslimah yang soleha, tapi ketika keluar dari masjid saya tergelincir dan kegelincir lagi, jangan-jangan saya ini munafik yaa. gimana ya $\mathrm{A}^{\prime}$ agar istikomah \& jadi hambanya yang terikat, terpaut dengan Nya Mohon tips nya A ? Assalammualaikum Wr.Wb"

Aa Gym : "Jadi sambil saya mendengar pertanyaan ibu, sambil saya mikir. Ini, ibu teh nyindir saya ngga yaa? Sama ibu, ini mah mewakili semua jamaah sepertinya yaa? Yang lainmah hanya terpendam, nah keluarnya lewat ibu. Betul begitu hadirin? Kalau ngga salah ada hadist nya yaa ustadz? Tentang ada sahabat nabi yang bicara, ketika deket dengan nabi, meni enak banget, tapi beda ketika jauh dari nabi.

Kalau ngga salah Rasulullah tuh mengingatkan, kalau engkau sama didalam dan diluar, para malaikat menyalamimu. Jadi memang bu. Ini mah suasananya juga beda, di masjid, malaikatnya juga menurunkan rahmat, memohonkan ampunan, yang dibahas juga tentang Allah. Yang hadir juga ingin deket ke Allah.

Faktanya diluar tidak sama seperti ini, bener? Dan itupun adalah hal yang manusiawi, jadi kita kesini teh di cash bu. Nah diluar mujahadahnya atau prakteknya, dan Allah memperhatikan. Nih yaa kita ngumpul disini nih pasti Allah yang ngatur, ngga ada satupun yang hadir, yang menyimak kecuali yang ditetapkan ilmu ini harus sampai kepadanya, maaf acungkan tangan yang pertama kali kesini.

Demi Allah pak, bapak ibu yang pertama kali kesini Allah yang 
ngatur, hari ini ada ilmu ini mudah-mudah manfaat Allah yang ngatur, sampai tuh pak. Tapi sesudah ini pasti dituntut oleh Allah diamalkan ngga nih ilmu ini? Jadi tiap kali ilmu sampai kekita pasti takdir Allah, dan allah melihat, kita mujahadah ngga mengamalkan ilmu. Masalahnya adalah banyak orang yang senang ilmu tapi belum tentu senang bermujahadah mengamalkannya." (Pengajian di Masjid Al Latief Blok M pasaraya pada tanggal 11 Februari 2017)

Berdasarkan kutipan percakapan dalam ceramah diatas, dapat disimpulkan bahwa percakapan Aa Gym sangat relevan dengan apa yang ditanyakan, tepat sasaran, sesuai, dan nyata. Indikatornya, ketika jamaah bertanya tentang keistikomahan, Aa Gym menjawab tentang istikomah juga, selain itu perkataan yang disampaikan benar adanya nyata, bisa diterima oleh akal, misalnya pada kutipan ini “...Jadi memang bu. Ini mah suasananya juga beda, di masjid, malaikatnya juga menurunkan rahmat, memohonkan ampunan, yang dibahas juga tentang Allah. Yang hadir juga ingin deket ke Allah. Faktanya diluar tidak sama seperti ini, bener? Dan itupun adalah hal yang manusiawi, jadi kita kesini teh di cash bu. Nah diluar mujahadahnya atau prakteknya, dan Allah memperhatikan.

Dalam hal ini, kutipan percakapan Aagym memenuhi kriteria percakapan yang relevan, dimana adanya relevansi antara apa yang ditanyakan oleh jamaah dan juga jawaan yang diberikan sehingga percapakannya terjalin efektif. Aturan relevansi ini dinyatakan bahwa agar terjadi kerja sama yang baik antara penutur dan mitra tutur, dimana masing-masing hendaknya dapat memberikan kontribusi yang relevan tentang suatu yang dipertuturkan. Dalam hal ini, antara AaGym dan jamaah terjalin kerjasama dimana kontribusi Aagym menjawab pertanyaan jamaah dengan jawaban yang relevan sesuai substansi permasalahan yang ditanyakan.

(4) Perkataan Berprilaku Aa Gym dalam dakwah nya 
W Dinata, RT Putri.

Perkataan berprilaku adalah perkataan yang jelas, tidak ambigu dan teratur. Lalu bagaimana dengan ceramah atau percakapan Aa Gym dengan jamaahnya, bisa dilihat kutipan ceramah beliau ketika mengisi ta'lim di Masjid Al Latief Jakarta.

Percakapan :

Jamaah : “Assalammualaikum. Saya ibu dari 4 orang anak, pada waktu anak saya kecil-kecil A, mudah sekali diatur, ketika denger adzan itudah berangkat semuanya, kemushola atau kemasjid, tapi begitu mereka sudah bekerja, kok kemesjid nya jadi berkurang, mereka tetep anak baik, sholat juga, taddarus juga, tapi untuk ke masjid nya ini, berjamaahnya ini, alasan nya duh mah aku capek, mama ngga saying aku nih, aku capek mah, jadi ketika dibangunin subuh, dia suka subuhnya setelah orang-orang keluar masjid dia baru solat subuh. Itu saya udah ngomong baik-baik, kemana yaa anak mama yang dulu manis, yang dulu alim, kok sekarang jadi begini..."

Aa Gym : “Kira-kira kalau diomongin begitu anaknya jadi Bahagia atau jadi nyesek bu?"

Jaamaah : "Dia cuman senyum aja..."

Aa Gym : "yaa itukan Nyesek Namanya buk yaa..”

Jamaah :" Hahaha"

Aa Gym : “Baik-baik, karena waktunya terbatas, saya boleh diijinin bantu jawab bu yaa?"

Jamaah: "Baik A"

Aa gym : "Ibu empat, saya amanahnya sebelas, dasar bukan bikinan saya yaa, semuanya bikinan Allah, beda-beda tuh sebelas tuh pak, ada yang disuruh juga udah tahajud, ada yang di dorongdorong juga, berat begitu. Tapi yakin aja, ini pasti lading amal bagi saya.

Tiap anak diperlakukan special masing-masing bu, dan 
posisi orang tua, bukan sebagai hakim, melainkan supportif, jadi kita bagian di bawah, kalau dia lupa kita bagian mengingatin, dia malas kita yang menyemangatin, dia tidak hati-hati kita yang menjaga, dia tergelincir kita yang memotivasi, dia salah kita yang mengingatin, pokoknya kita hanya sebagai supporting. Nah jadinya orang semangat itu kalau kita jadi supporting, orang ngga akan nyaman tuh, kalau kita diatas jadi hakim. Makanya kalau bisa mah hindarin aja perkataan tadi bu, karena itu lebih menyindir yaa". (Pengajian di Masjid Al Latief Blok M pasaraya pada tanggal 11 Februari 2017)

Berdasarkan kutipan ceramah di atas dapat kita pelajari bahwa komunikasi Aa gym dengan jamaah sudah memenuhi atau tidak melanggar kriteria perkataan berprilaku (manner maxim) yang mana, tidak jelas, ambigu, dan tidak teratur. Melainkan komunikasinya jelas, jawabannya focus pada pertanyaan, dan teratur atau terstruktur step by step nya.

Dalam hal ini, kutipan percakapan tersebut sesuai dengan kriteria percakapan yang berperilaku, dimana penutur memberikan kontribusi dengan jelas, yaitu kontribusi yang menghindari ketidakjelasan, dimana Aa Gym memberikan kontribusi dengan jawaban yang jelas, tidak ambigu sehingga tidak membuat jamaah bingung akan jawaban yang diberikan, artinya Aa Gym berusaha memberikan jawaban yang sekiranya dapat dipahami oleh jamaah, sehingga jamaah dapat memahami jawaban dari apa yang ia tidak pahami sebelumnya, penuturan jawaban yang foku pada permasalahan yang ditanyakan sehingga percakapan tidak melebar kemana-mana.

\section{PENUTUP}


W Dinata, RT Putri.

Berdasarkan hasil temuan masalah dapat disimpulkan bahwa aturan percakapan dalam ceramah atau dakwah Aa Gym memenuhi standart teori aturan percakapan yang ditemukan oleh Paul Grice yang mana percakapan Aa Gym dengan jamaahnya menggunakan :

Pertama, perkataan berkuantitas (quantity maxim), dimana percakapan yang terjalin antara Aa Gym dan jamaah bersifat infromatif atau memberikan informasinya yang cukup, relatif memadai, namun tidak melebihi informasi yang dibutuhkan oleh jamaah, selain itu juga perkataannya yang efektive dan efisien, singkat, padat, dan jelas.

Kedua, ceramah Aa gym memenuhi aturan percakapan perkataan berkualitas (quality maxim), dimana Aa Gym memberikan informasi yang sesuai dengan kenyataan dan menjunjung tinggi kejujuran, tidak dilebih-lebihkan, apa adanya, dan disampaikan dari lubuk hatinya, terbukti ceramahnya menyentuh hati.

Ketiga ceramah Aa gym juga memenuhi aturan percakapan dengan perkataan relevan (relevancy maxim), dimana dalam setiap informasi yang disampaikannya relevan dengan permasalahan utama yang sedang dibahas, adanya saling keterkaitan satu bahasan ke bahasan yang lain.

Keempat, ceramah Aa gym juga memenuhi aturan percakapan perkataan berprilaku (manner maxim). Yang mana komunikasinya jelas, jawabannya focus pada pertanyaan, dan teratur atau terstruktur step by step nya. bukan sebaliknya, ambigu, tidak jelas, dan tidak teratur.

Keempat hal ini menjadi pendukung terwujudnya komunikasi yang efektif, dimana informasi yang disampaikan ataupun yang diterima tepat sesuai sasaran dan memberikan pemahaman makna yang mendalam bagi jamaah, sehingga membuat jamaah berkeinginan untuk mengikuti kajian Aa gym secara rutin.

Selain itu dengan adanya kesesuaian antara percakapan dalam 
ceramah Aa Gym dengan standar aturan percakapan sesuai teori Paul Grice, maka ini menjadi sebuah ikhtiar yang dilakukan Aa Gym sebagai pendakwah untuk bagaimana caranya mencoba berdakwah, menyampaikan ajaran Islam kepada jamaah dengan memerhatikan aspek spriritual juga aspek psikologis jamaah sehingga isi ceramah yang disampaikan oleh Aa Gym ini dapat diterima, dipahami, dimaknai secara positif yang berkemungkinan dapat tertanam di benak jamaah sehingga tujuan dakwah yang dilakukan oleh Aa Gym terwujud dengan baik.

\section{DAFTAR PUSTAKA}

A.Markarma. (2014). KOMUNIKASI DAKWAH EFEKTIF DALAM PERSPEKTIF ALQURAN. Jurnal Hunafa: Vol. 11, No. 1, Juni 2014: 127151.

Gymnastiar, Abdullah. 2005. Aa Gym Apa Adanya: Sebuah Qolbugrafi. Bandung: Khas MQ.

Jaobs, S., \& Dawson, E. J., Brashers, D. (1996). information manipulation Theory: A replication and Assessment, Communication Monograph.

Mey, Jacob L.Pragmatics (2001). An Introduction Australia :Blackwell Publishing.

Morissan. (2013). Teori Komunikasi: Individu hingga massa, Jakarta: Penerbit Prenadamedia Group.

Nuh, Sayyid Muhammad. Strategi Dakwah dan Pendidikan Umat.

Yogyakarta: Himam Prisme Medi, 2004.

Rahardjo, D. (1995). Pesatren dan Pembaharuan. Jakarta: LP3ES.

Rustono. 1998. Implikatur Percakapan sebagai Pengungkapan Humor di dalam Wacana Humor Verbal Lisan Berbahasa Indonesia. Jakarta: Universitas Indonesia Press

Soewardi. H. (2003). Akhirnya Sains Barat Sekular Kandas. Bandung: Bakti Mandiri.

Thaha, Idris (Ed.). 1997. Dakwah dan Politik Da'i Berjuta Umat K.H. Zainuddin MZ. Bandung: Mizan. 
W Dinata, RT Putri.

Wijana, I Dewa Putu. 1996. Dasar-dasar Pragmatik. Yogyakarta: Andi Offset

Wijaya, H. A. W. 2000. Ilmu Komunikasi Pengantar Studi. Jakarta: Rineka Cipta.

Jurnal:

Muliawan, Dadang, \& Ramdani, I. (2020). PESAN DAKWAH DALAM PROGRAM ACARA MUSLIM TRAVELERS NET TV. Iktisyaf: Jurnal Ilmu Dakwah Dan Tasawuf, 2(2), 69-87. Diambil dari https://jurnal.stidsirnarasa.ac.id/index.php/iktisyaf/article/view/21 